\title{
A transient study of double-jacketed membrane reactor via methanol steam reforming
}

\author{
Chi-Hua Fu, Jeffrey C.S. Wu* \\ Department of Chemical Engineering, National Taiwan University, No. 1, Section 4, Roosevelt Road, Taipei, Taiwan 10617, ROC
}

\section{A R T I C L E I N F O}

Article history:

Received 20 August 2008

Received in revised form

2 October 2008

Accepted 2 October 2008

Published online

Keywords:

Double-jacketed membrane reactor

Methanol steam reforming

Unsteady state

Transient

Simulation

\begin{abstract}
A B S T R A C T
A non-isothermal unsteady-state model was established to simulate methanol steam reforming using a double-jacketed Pd membrane reactor. At steady state, a self-sustained membrane reactor was achieved by the oxidation of residual methanol and hydrogen from reformer for endothermic steam reforming. The molar fractions of species and reformer temperature were analyzed under co-current operation between oxidation and reformer sides. The start-up of reformer was simulated under two conditions: (1) The catalyst temperature was lower than the influent temperature and (2) The catalyst temperature was higher than influent temperature. Condition 1 yielded higher methanol conversion and reformer temperature than condition 2 at steady state. Moreover, the instability of species can be minimized on condition 1 during start-up. The fluctuation of membrane reactor at steady state was also studied. Two strategies were compared to analyze the reformer response when temporary extra hydrogen was required. The results showed that increasing inlet methanol outperformed increasing reformer temperature.
\end{abstract}

() 2008 International Association for Hydrogen Energy. Published by Elsevier Ltd. All rights reserved.

\section{Introduction}

Research in hydrogen generation has drawn much attention in recent years [1-5]. Due to the difficulties of storage and transportation, the integration of hydrogen formation and purification shows the competitive advantage over traditional processes such as pressure swing adsorption or cryogenic technology. Simultaneous hydrogen formation and purification can accelerate the reaction rate, leading to a higher conversion or lower reaction temperature than that of traditional processes. Of all the studies of hydrogen production processes, steam reforming of hydrogen-rich fuel combined with the permeation of a supported membrane reactor shows competitiveness in this field [1-3,6,7]. However, the steam reforming of fuel is highly endothermic, and therefore external heat is needed to drive the reactions. Autothermal reforming is to add a small amount of oxygen in the feedstock, thus the necessary heat for the endothermic steam reforming can be supplied by the exothermic oxidation of fuel [8-11]. A mixture of fuel, steam, and oxygen (or air) is fed into the reactor, where steam reforming and catalytic partial oxidation take place in one system. The advantages of autothermal reforming are simple reactor design, less heat transfer resistances and fast start-up time. However, it is hard to adjust the oxygen to fuel ratio to meet the thermal-neutral condition. The partial oxidation of fuel yields high carbon monoxide concentration, which is an undesirable product [12].

Using the external oxidation reactor is an alternate option that can prevent several drawbacks to the autothermal reactor, though external heat transfer causes heat resistance problems. The additional catalytic combustor has higher costs than that of an all-in-one system. However, separating the catalytic oxidation and steam reforming to different systems can simplify reactions, leading to more hydrogen permeation

\footnotetext{
* Corresponding author. Tel.: +886 223631994; fax: +886 223623040 .

E-mail address: cswu@ntu.edu.tw (J.C.S. Wu).
}

0360-3199/\$ - see front matter () 2008 International Association for Hydrogen Energy. Published by Elsevier Ltd. All rights reserved. doi:10.1016/j.ijhydene.2008.10.005 


\begin{tabular}{|c|c|c|c|}
\hline \multicolumn{2}{|c|}{ Nomenclature } & $r_{\mathrm{i}}^{\mathrm{s}}$ & reaction rate of $i$ species on catalyst surface, $\mathrm{mol} /$ \\
\hline$A_{c}$ & cross-section area of reformer, $\mathrm{m}^{2}$ & & 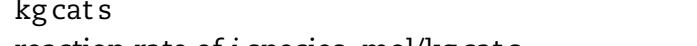 \\
\hline$A_{m}$ & permeation area per unit volume, $\mathrm{m}^{2} / \mathrm{m}^{3}$ & $r_{j}$ & reaction rate of $j$ species, $\mathrm{mol} / \mathrm{kg}$ cat $\mathrm{s}$ \\
\hline$A_{\circ}$ & $\begin{array}{l}\text { heat transfer area between reformer and catalytic } \\
\text { combustor, } \mathrm{m}^{2}\end{array}$ & $\begin{array}{l}r_{\mathrm{p}} \\
\mathrm{S}_{\mathrm{a}}\end{array}$ & heat transfer area per volume of catalyst, $\mathrm{m}^{2} / \mathrm{m}^{3}$ \\
\hline $\mathrm{C}$ & concentration, $\mathrm{mol} / \mathrm{m}^{3}$ & $\mathrm{~T}$ & temperature, $\mathrm{K}$ \\
\hline$C p$ & average heat capacity, $\mathrm{J} / \mathrm{m} \mathrm{K}$ & $t$ & time, $\mathrm{s}$ \\
\hline $\mathrm{De}_{i}$ & effective gas diffusivity, $\mathrm{m}^{2} / \mathrm{s}$ & $U_{1}$ & overall heat transfer coefficient between reformer \\
\hline $\begin{array}{l}\mathrm{De}_{i, p} \\
d_{\mathrm{p}}\end{array}$ & $\begin{array}{l}\text { effective gas diffusivity inside the catalyst, } \mathrm{m}^{2} / \mathrm{s} \\
\text { catalyst particle diameter, } \mathrm{m}\end{array}$ & $U_{2}$ & overall heat transfer coefficient between reformer \\
\hline$d_{\mathrm{m}}$ & membrane thickness, $\mathrm{m}$ & $u$ & superficial velocity, $\mathrm{m}$ \\
\hline$d_{0}$ & wall thickness of outer jacket, m & $\mathrm{V}$ & volume, $\mathrm{m}^{3}$ \\
\hline$d_{\mathrm{s}}$ & thickness of Pd membrane support, $\mathrm{m}$ & WHSV & weight hourly space velocity, $\mathrm{h}^{-1}$ \\
\hline$G_{0}$ & mass flow flux, $\mathrm{kg} / \mathrm{m}^{2} \mathrm{~s}$ & $x$ & molar fraction (Eq. (18)) \\
\hline$h_{\mathrm{r}}$ & $\begin{array}{l}\text { effective heat transfer coefficient in reformer, } \\
\mathrm{W} / \mathrm{m}^{2} \mathrm{~K}\end{array}$ & $X$ & methanol conversion (Eq. (3)) \\
\hline$h_{\circ}$ & $\begin{array}{l}\text { effective heat transfer coefficient in catalytic } \\
\text { combustor, } \mathrm{W} / \mathrm{m}^{2} \mathrm{~K}\end{array}$ & $\begin{array}{l}\mathrm{Z} \\
\Delta \mathrm{H}\end{array}$ & $\begin{array}{l}\text { axial coordinate of reactor, } \mathrm{m} \\
\text { reaction enthalpy, } \mathrm{J} / \mathrm{mol}\end{array}$ \\
\hline$h_{\mathrm{p}}$ & effective heat transfer coefficient in permeator, & Greek le & ters \\
\hline & $\mathrm{W} / \mathrm{m}^{2} \mathrm{~K}$ & $\beta$ & permeation coefficient of Pd membrane, mol/ \\
\hline$j_{H}$ & Chilton-Colburn factor & & $\mathrm{ms} \mathrm{atm}^{1 / 2}$ \\
\hline $\mathrm{J}_{\mathrm{H}_{2}}$ & mass flux of hydrogen from reformer to & $\varepsilon$ & void fraction \\
\hline & permeator, $\mathrm{mol} /\left(\mathrm{m}^{2} \mathrm{~s}\right)$ & $\eta$ & effectiveness factor \\
\hline$k_{\mathrm{r}}$ & catalyst heat conductivity, $\mathrm{W} / \mathrm{m} \mathrm{K}$ & $\rho$ & density, $\mathrm{kg} / \mathrm{m}^{3}$ \\
\hline$k_{\mathrm{m}}$ & heat conductivity of membrane, W/m K & $\tau$ & tortuosity factor \\
\hline$k_{\mathrm{p}}$ & gas heat conductivity in permeator, $\mathrm{W} / \mathrm{m} \mathrm{K}$ & $\mu$ & viscosity, $\mathrm{kg} / \mathrm{ms}$ \\
\hline$k_{\mathrm{o}}$ & heat conductivity of outer jacket, $\mathrm{W} / \mathrm{m} \mathrm{K}$ & $v$ & molar volume, $\mathrm{m}^{3} / \mathrm{mol}$ \\
\hline$k_{\mathrm{s}}$ & heat conductivity of Pd membrane support, W/m K & Subscri & \\
\hline L & reactor length, m & 0 & initial \\
\hline M & molecular weight, g/mol & & gas \\
\hline$P_{i}$ & pressure, atm & $\begin{array}{l}g \\
i\end{array}$ & gas \\
\hline$P_{i}$ & partial pressure of $i$ species, $\mathrm{Pa}$ & & component number in reformer \\
\hline$P_{\mathrm{H}_{2}}$ & hydrogen partial pressure, atm & & component number in catalytic combustor \\
\hline $\operatorname{Pr}$ & Prandtl number & $\mathrm{H}_{2}$ & hydrogen \\
\hline$R$ & ideal gas constant, atm L/(mol K) & meth & l methanol \\
\hline $\operatorname{Re}$ & Reynolds number & 0 & oxidation \\
\hline$R_{\mathrm{W} / \mathrm{M}}$ & molar ratio between water and methanol & $\mathrm{p}$ & permeation \\
\hline$r$ & catalyst particle radius, $\mathrm{m}$ & $\mathrm{r}$ & reforming \\
\hline$r_{i}$ & reaction rate of $\mathrm{i}$ species, $\mathrm{mol} / \mathrm{kg}$ cat s & $\mathrm{s}$ & catalyst \\
\hline
\end{tabular}

and lower carbon monoxide concentration. Using competitive oxidative catalysts, such as $\mathrm{Pt} / \mathrm{Al}_{2} \mathrm{O}_{3}$ or $\mathrm{Pd} / \mathrm{Al}_{2} \mathrm{O}_{3}$ in the external oxidation reactor, have higher heat generation efficiency of fuel than that of using reforming catalysts. Han et al. studied an on-site hydrogen generator with a steam reformer, a hydrogen permeator and a catalytic combustor [13]. When the system reaches steady state, methanol is almost converted completely, and results in $65 \%$ of hydrogen. After the hydrogen purification by a $\mathrm{Pd}-\mathrm{Cu}$ alloy membrane, hydrogen recovery can reach $75 \%$. The remaining $25 \%$ hydrogen can be oxidized to supply the heat for steam reforming.

Previous researchers have done some detailed studies on the hydrogen generation using membrane reactors by simulation. Harold et al. used an one-dimensional isothermal model of palladium supported membrane reactor to study different kinds of hydrogen generation for fuel cell applications. Later, a comparison of conventional and autothermal membrane reactors was studied. They concluded that a smaller size autothermal membrane reactor can give the same hydrogen generation as that of a conventional one [14-16]. Ji et al. used an one-dimensional non-isothermal heterogeneous model to simulate the methane membrane reactor. An optimal operation point is presented to balance the equipment investment, hydrogen production rate and overall energy efficiency [17]. Chan's group used a twodimensional non-isothermal unsteady-state model to simulate the autothermal reforming of methane and the results were validated with experimental data. The prediction showed that the reformer could reach steady state within $5 \mathrm{~min}$ after the preheating treatment of reformer. Further studies found the optimal air to methane, steam to methane ratio, and the space velocity [18-20].

So far, although reforming in membrane reactors has been studied extensively, most of the studies focused on finding the 
optimal operation at steady-state by adjusting the inlet compositions, reformer pressure, temperature, and reactor design. On the other hand, only a few researchers studied the autothermal reforming process under unsteady-state conditions [19-21]. The research work on membrane reformers with external heat supplement under unsteady state is still unclear. In our previous study, we used a 1-D non-isothermal model to simulate the hydrogen production using a self-sustained double-jacketed membrane reactor under steady state [22]. However, during the transient period, species variations and reformer temperature fluctuations are difficult to measure by experimental study, and thus the optimum operating strategy is hard to acquire. It is important to understand the reformer response during the transient period. The optimal control as well as the corresponding strategy should be studied thoroughly when species and/or temperature variations occur at the start-up. Through a simulation study, the results allow us to choose an optimal start-up strategy and can be used as a guideline for experiments. When double-jacketed membrane reactors are running under unsteady state, the responses of mass and temperature variations in the permeator, reformer and combustor should be considered simultaneously. The main concern is how fast the reactor can reach steady state from start-up. How long it would take to return to steady state when a mass or temperature disturbance occurs.

The objective of this study is to simulate the nonisothermal unsteady state of a double-jacketed membrane reactor in methanol steam reforming. In particular, during start-up, the consumption and production of species in the steam reformer and the temperatures of gases and catalysts are investigated under two conditions: (1) the temperature of inlet feed is higher than that of catalyst; (2) the temperature of catalyst bed is higher than that of inlet feed. A special situation is also considered when a temporary extra hydrogen demand occurs under steady-state operation.

\section{Kinetics and mathematical model}

\subsection{Reaction kinetics}

Methanol is one of the hydrogen-rich fuels used in membrane reactors. Using methanol as the reforming gas has been studied extensively in recent years [9-11,14,16,23,24]. Methanol is in liquid state at room temperature and atmospheric pressure, and can be easily stored and transported. Methanol has high hydrogen to carbon ratio and the absence of carbon to carbon bonds can produce high hydrogen yield and low carbon dioxide. Methanol steam reforming can be operated under lower temperature than that of other hydrocarbons such as methane or gasoline. The overall reaction of methanol steam reforming can be expressed in Eq. (1)

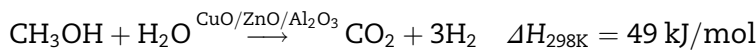

A comprehensive kinetic model was developed by Peppley et al. $[23,24]$ over a commercial $\mathrm{CuO} / \mathrm{ZnO} / \mathrm{Al}_{2} \mathrm{O}_{3}$ catalyst. The results showed that methanol decomposition is the slowest, as compared to the steam reforming and water-gas shift, because it takes place on different active sites. Therefore carbon monoxide is one of the byproducts and is depended on the reformer operating conditions. Besides steam reforming, methanol decomposition and water gas shift are also incorporated in this model. The details of the kinetic model are shown in Appendix.

The reaction expression of methanol catalytic oxidation on $\mathrm{Pt} / \gamma-\mathrm{Al}_{2} \mathrm{O}_{3}$ is depicted in Eq. (2), with a power law kinetic equation shown in Eq. (3) [25].

$$
\mathrm{CH}_{3} \mathrm{OH}+1.5 \mathrm{O}_{2} \stackrel{\mathrm{Pt} / \gamma-\mathrm{Al}_{2} \mathrm{O}_{3}}{\rightarrow} \mathrm{CO}_{2}+2 \mathrm{H}_{2} \mathrm{O} \quad \Delta \mathrm{H}_{298 \mathrm{~K}}=-676 \mathrm{~kJ} / \mathrm{mol}
$$

$\begin{aligned} r_{\mathrm{o}} & =4.691 \times 10^{9} \mathrm{e}^{-48,500 / \mathrm{RT}} C_{\text {methanol }}^{1.4} \mathrm{X}<12 \% \\ & =3.153 \times 10^{6} \mathrm{e}^{-18,100 / \mathrm{RT}} C_{\text {methanol }}^{1.4} \mathrm{X}>12 \%\end{aligned}$

There are few researches which studied the reaction kinetics of hydrogen catalytic oxidation on $\mathrm{Pt} / \gamma-\mathrm{Al}_{2} \mathrm{O}_{3}$. We assume that the reaction rate of hydrogen catalytic oxidation is the same as methanol catalytic oxidation. The variation of oxidation rate won't appreciably affect the simulation because oxidation is much faster than reforming. The $\mathrm{CO}$ oxidation is neglected because the $\mathrm{CO}$ amount is much fewer than methanol and hydrogen.

\subsection{Mathematical model}

Methanol steam reforming in a membrane reactor is simulated using an one-dimensional non-isothermal unsteady-state model. Fig. 1 shows the schematic diagram of a double-jacketed membrane reactor. From the outer layer to the inner layer are the catalytic combustor, reformer and permeator, respectively. The catalytic combustor is filled with oxidative catalysts such as $\mathrm{Pt} / \mathrm{Al}_{2} \mathrm{O}_{3}$ or $\mathrm{Pd} / \mathrm{Al}_{2} \mathrm{O}_{3}$. The reformer is filled with reforming catalyst $\mathrm{CuO} / \mathrm{ZnO} / \mathrm{Al}_{2} \mathrm{O}_{3}$. A palladium membrane is coated on the surface of the permeator due to the $100 \%$ hydrogen permselectivity of palladium. Therefore pure hydrogen can be obtained from the permeator. The mass and energy balances are evaluated simultaneously in three parts. Some assumptions are made to simplify calculations. The concentration and temperature gradient in the radial axis is neglected based on plug flow reactor assumption. The mass and thermal diffusion is negligible, when compared with the convection and conduction of mass and enthalpy. The physical and chemical properties of gases and catalysts are evaluated based on the average values of theoretical or experimental data which are shown in Table 1 . The governing equations and boundary conditions are listed below, with their symbols and definitions shown in nomenclature.

Mass balances

1. Reformer

$$
\begin{gathered}
\varepsilon \frac{\partial C_{i}}{\partial t}+u_{\mathrm{r}} \frac{\partial C_{i}}{\partial z}=\eta_{i} \rho_{s, r}\left(-r_{i}\right), \quad\left(i=\mathrm{CH}_{3} \mathrm{OH}, \mathrm{H}_{2} \mathrm{O}, \mathrm{CO}_{2}, \mathrm{CO}\right) \\
\varepsilon \frac{\partial C_{\mathrm{H}_{2}}}{\partial t}+u_{\mathrm{r}} \frac{\partial C_{\mathrm{H}_{2}}}{\partial z}=\eta_{\mathrm{H}_{2}} \rho_{\mathrm{s}, \mathrm{r}}\left(r_{\mathrm{H}_{2}}\right)-\frac{\beta}{d_{\mathrm{m}}} A_{\mathrm{m}}\left(\sqrt{\mathrm{P}_{\mathrm{H}_{2}, \mathrm{r}}}-\sqrt{\mathrm{P}_{\mathrm{H}_{2}, \mathrm{p}}}\right)
\end{gathered}
$$

\section{Permeator}

$$
\frac{\partial C_{\mathrm{H}_{2}}}{\partial t}+u_{\mathrm{p}} \frac{\partial C_{\mathrm{H}_{2}}}{\partial z}=\frac{\beta}{d_{m}} A_{m}\left(\sqrt{P_{\mathrm{H}_{2}, \mathrm{r}}}-\sqrt{\mathrm{P}_{\mathrm{H}_{2}, \mathrm{p}}}\right)
$$




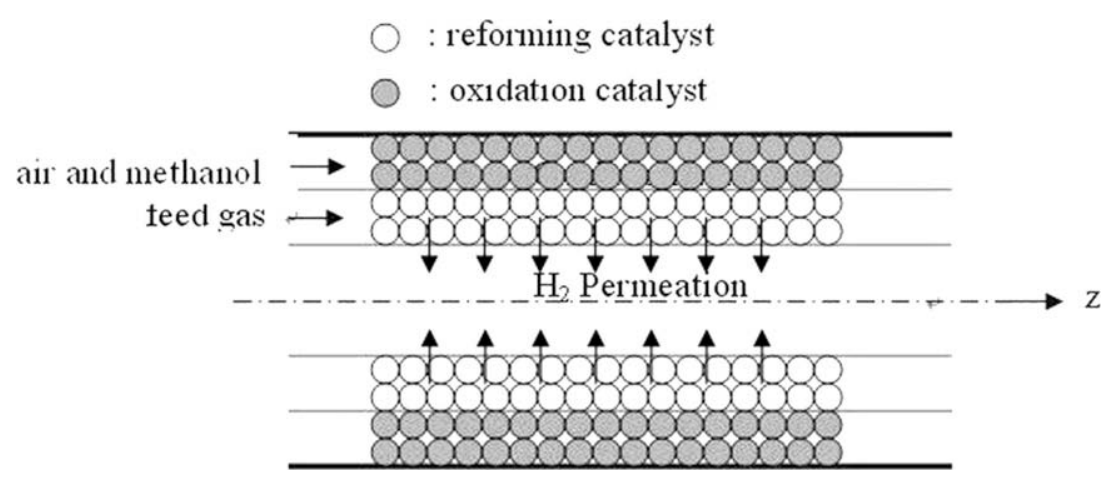

Fig. 1 - Schematic diagram of a double-jacketed Pd membrane reactor.

\section{Oxidation side}

$\varepsilon \frac{\partial C_{j}}{\partial t}+u_{o} \frac{\partial C_{j}}{\partial z}=\eta_{j} \rho_{s, o}\left(-r_{j}\right), \quad\left(j=\mathrm{CH}_{3} \mathrm{OH}, \mathrm{O}_{2}, \mathrm{H}_{2}, \mathrm{H}_{2} \mathrm{O}, \mathrm{CO}_{2}\right)$

Energy balance

1. Reformer

$$
\begin{aligned}
\rho_{\mathrm{g}, \mathrm{r}} C p_{\mathrm{g}, \mathrm{r}}\left(\varepsilon \frac{\partial \mathrm{T}_{\mathrm{g}, \mathrm{r}}}{\partial \mathrm{t}}+u_{\mathrm{r}} \frac{\partial \mathrm{T}_{\mathrm{g}, \mathrm{r}}}{\partial z}\right)= & U_{1} A_{\circ}\left(T_{\mathrm{o}}-T_{\mathrm{g}, \mathrm{r}}\right)-U_{2} A_{\mathrm{m}}\left(T_{\mathrm{g}, \mathrm{r}}-\mathrm{T}_{\mathrm{p}}\right) \\
& -\mathrm{S}_{\mathrm{a}} h_{\mathrm{r}}\left(\mathrm{T}_{\mathrm{g}, \mathrm{r}}-\mathrm{T}_{\mathrm{s}, \mathrm{r}}\right)
\end{aligned}
$$$$
\rho_{\mathrm{s}, \mathrm{r}} C p_{\mathrm{s}, \mathrm{r}} \frac{\partial \mathrm{T}_{\mathrm{s}, \mathrm{r}}}{\partial \mathrm{t}}=k_{\mathrm{r}} \frac{\partial^{2} \mathrm{~T}_{\mathrm{s}, \mathrm{r}}}{\partial \mathrm{z}^{2}}+\eta_{\mathrm{i}} \rho_{\mathrm{s}, \mathrm{r}}\left(-r_{\mathrm{i}}\right) \Delta H_{\mathrm{i}}+\mathrm{S}_{\mathrm{a}} h_{\mathrm{r}}\left(\mathrm{T}_{\mathrm{g}, \mathrm{r}}-\mathrm{T}_{\mathrm{s}, \mathrm{r}}\right)
$$

\section{Permeator}

$$
\rho_{\mathrm{H}_{2}} C p_{\mathrm{H}_{2}}\left(\frac{\partial \mathrm{T}_{\mathrm{p}}}{\partial \mathrm{t}}+u_{\mathrm{p}} \frac{\partial \mathrm{T}_{\mathrm{p}}}{\partial \mathrm{z}}\right)=\left(J_{\mathrm{H}_{2}} C p_{\mathrm{H}_{2}}+U_{2} \mathrm{~A}_{\mathrm{m}}\right)\left(\mathrm{T}_{\mathrm{g}, \mathrm{r}}-\mathrm{T}_{\mathrm{p}}\right)
$$

3. Oxidation side

$$
\rho_{\mathrm{g}, \mathrm{o}} C p_{\mathrm{g}, \mathrm{o}}\left(\varepsilon \frac{\partial \mathrm{T}_{\mathrm{o}}}{\partial \mathrm{t}}+u_{\mathrm{o}} \frac{\partial \mathrm{T}_{\mathrm{o}}}{\partial z}\right)=\eta_{j} \rho_{\mathrm{s}, \mathrm{o}}\left(-r_{j}\right) \Delta H_{j}-U_{1} \mathrm{~A}_{\mathrm{o}}\left(\mathrm{T}_{\mathrm{o}}-\mathrm{T}_{\mathrm{g}, \mathrm{r}}\right)
$$

\section{Table 1 - Parameters of reactor used in the simulation}

$\begin{array}{lc}\text { Permeator radius } r_{\mathrm{p}}(\mathrm{m}) & 6.35 \times 10^{-3} \\ \text { Reformer radius } r_{\mathrm{r}}(\mathrm{m}) & 1.27 \times 10^{-2} \\ \text { Combustor radius } r_{\mathrm{o}}(\mathrm{m}) & 1.91 \times 10^{-2} \\ \text { Reformer length } \mathrm{L}(\mathrm{m}) & 1.0 \times 10^{-1} \\ \text { Membrane thickness } d(\mathrm{~m}) & 1.0 \times 10^{-5} \\ \quad \text { Catalyst density } \rho_{\mathrm{s}}\left(\mathrm{kg} \mathrm{m}^{-3}\right) & 1300 \\ \quad \begin{array}{l}\text { Surface area } \\ \quad \text { of catalyst } \mathrm{S}_{\mathrm{a}}\left(\mathrm{m}^{2} \mathrm{~kg}^{-1}\right)\end{array} & 56,000 \\ \quad \begin{array}{l}\text { Catalyst particle } \\ \quad \text { diameter } \mathrm{d}_{\mathrm{p}}(\mathrm{m})\end{array} & 2.0 \times 10^{-3} \\ \quad \begin{array}{l}\text { Hydrogen permeability } \\ \quad \text { over Pd membrane } \beta\left(\mathrm{mol} \mathrm{m}^{-1} \mathrm{~s}^{-1} \mathrm{~atm}^{-0.5}\right)\end{array} \\ \quad\end{array}$

\subsection{Boundary conditions}

$\mathrm{z}=0, \quad C_{i}=C_{i, 0}, \quad C_{j}=C_{j, 0}, \quad C_{H_{2}}=0$ (permeator)

$\mathrm{T}_{\mathrm{g}, \mathrm{r}}=\mathrm{T}_{\mathrm{g}, \mathrm{r}, 0}, \quad k_{\mathrm{r}} \frac{\partial \mathrm{T}_{\mathrm{s}, \mathrm{r}}}{\partial \mathrm{z}}=h_{\mathrm{r}} A_{\mathrm{c}}\left(\mathrm{T}_{\mathrm{g}, \mathrm{r}, 0}-\mathrm{T}_{\mathrm{s}, \mathrm{r}, 0}\right), \quad \mathrm{T}_{\mathrm{p}}=\mathrm{T}_{\mathrm{p}, 0}, \quad \mathrm{~T}_{\mathrm{o}}=\mathrm{T}_{\mathrm{o}, 0}$

$z=1, \quad \frac{\partial T_{s, r}}{\partial z}=0$

$t=0^{+}, \quad C_{i}=C_{i, 0}, \quad C_{j}=C_{j, 0}, \quad C_{\mathrm{H}_{2}}=0$ (permeator)

$\mathrm{T}_{\mathrm{g}, \mathrm{r}}=\mathrm{T}_{\mathrm{g}, \mathrm{r}, 0}, \mathrm{~T}_{\mathrm{s}, \mathrm{r}}=\mathrm{T}_{\mathrm{s}, \mathrm{r}, 0}, \mathrm{~T}_{\mathrm{p}}=\mathrm{T}_{\mathrm{p}, 0}, \mathrm{~T}_{\mathrm{o}}=\mathrm{T}_{\mathrm{o}, 0}$

The hydrogen permeability through Pd membrane is taken from Uemiya et al. [1]:

$\beta=1.567 \times 10^{-5} \mathrm{e}^{-8410 / \mathrm{RT}}$

The effectiveness factor, $\eta_{i}$, is a function of temperature, the effective diffusivity and the species partial pressure in catalyst. A continuity equation is used to calculate $\eta_{i}$.

$\operatorname{De}_{i, p}\left(\frac{d^{2} P_{i}}{d r^{2}}+\frac{1}{r} \frac{d P_{i}}{d r}\right)=\rho_{s} r_{i}$

$\eta_{i}=\frac{\int_{0}^{\mathrm{V}} \rho_{\mathrm{s}} r_{i} \frac{\mathrm{d} V^{\prime}}{V}}{\rho_{\mathrm{s}} r_{i}^{\mathrm{s}}}$

where the effective diffusivities of species inside the catalyst are calculated by [26].

$\mathrm{De}_{\mathrm{i}, \mathrm{p}}=\frac{\varepsilon}{\tau} \mathrm{De}_{\mathrm{i}}$

where $\varepsilon$ is the void fraction and $\tau$ read as the tortuosity factor.

The effective diffusivities $\mathrm{De}_{i}$ are given by [27]

$\mathrm{De}_{i}=\frac{1}{\left(1-x_{i}\right)} \sum_{j=1, j \neq i}^{n} D e_{i, j} x_{j}$

where the binary diffusivities are estimated by Fuller-Schettler-Giddings correlation [28].

$D e_{i, j}=\frac{0.00101 \times T^{1.75} M_{i, j}^{1 / 2}}{P\left[\left(\sum v\right)_{i}^{1 / 3}+\left(\sum v\right)_{j}^{1 / 3}\right]^{2}}$

$U_{1}$ and $U_{2}$ are the overall heat transfer coefficients of reformer/ combustor and permeator/reformer side, respectively. They are given by the following expressions

$U_{1}=\left(\frac{1}{h_{\mathrm{r}}}+\frac{d_{\mathrm{o}}}{k_{\mathrm{o}}}+\frac{1}{h_{\mathrm{o}}}\right)^{-1}$ 
$U_{2}=\left(\frac{1}{h_{\mathrm{p}}}+\frac{d_{\mathrm{m}}}{k_{\mathrm{m}}}+\frac{d_{\mathrm{s}}}{k_{\mathrm{s}}}+\frac{1}{h_{\mathrm{r}}}\right)^{-1}$

The effective heat transfer coefficients, $h_{\mathrm{r}}$ or $h_{\mathrm{o}}$, are evaluated by Chilton-Colburn factor $j_{\mathrm{H}}$ [27].

The Chilton-Colburn factor of gas through packed beds can be described as follows.

$j_{\mathrm{H}}=2.19 R e^{-2 / 3}+0.78 \operatorname{Re}^{-0.381}=\frac{h_{\mathrm{r}}}{\mathrm{CpG}_{0}} \operatorname{Pr}^{2 / 3}$

The gas heat transfer coefficient in permeator is calculated by the Colburn correlation [28].

$h_{\mathrm{p}}=0.023 \frac{k_{\mathrm{p}}}{r_{\mathrm{p}}} \operatorname{Re}^{0.8} \operatorname{Pr}^{1 / 3}$

To simplify the physical interpretation, some dimensionless groups are used to generalize and analyze the results. The dimensionless groups are presented in Eq. (24)

$z^{*}=\frac{z}{L}, t^{*}=\frac{t}{L / u_{0}}, \quad C_{i}^{*}=\frac{C_{i}}{C_{\text {methanol }, 0}}, T^{*}=\frac{T}{T_{0}}$

Using dimensionless groups is helpful for scaling-up. For instance, dimensionless time is the real time divided by space time of reactants in the reactor. Therefore, a large reactor with long space time has the same dimensionless time as a small reactor with short space time.

The species concentration and temperature are solved by finite difference method with $100 \times 50$ matrix using the Mathematica.

\section{Results and discussions}

\subsection{Variation of temperatures and concentrations during start-up period}

Before the reactor starts up, the catalyst bed and inlet feed should be preheated to the working temperature. However, it takes a long time and a lot of enthalpy to heat up the reformer and inlet feed. One may think that it is possible to heat up the reformer or inlet gases to a temperature lower than the working temperature to save preheating time or cost, and thus an interesting consideration is proposed. A transient simulation is carried out from the start of inlet feed till the reformer reaches steady state. The main concern is how fast the reformer can fully reach steady state, therefore, the prediction is estimated based on two conditions, (1) the hot inlet feed is set to be $543 \mathrm{~K}$, and the cold catalyst bed is $433 \mathrm{~K}$, which is the minimum temperature of the kinetic data proposed by Peppley et al. $[23,24],(2)$ the cold inlet feed is set to be $433 \mathrm{~K}$, and the hot catalyst bed is $543 \mathrm{~K}$. The reason for choosing $433-543 \mathrm{~K}$ is because methanol steam reforming is usually operated in this region. In addition, we expect a fast start-up time or less preheating costs when either gas stream or catalyst starts at low temperature. The initial temperature of the catalytic combustor is set to be $543 \mathrm{~K}$, that is, methanol mixed with air at $543 \mathrm{~K}$ is fed into the catalytic combustor with the oxidative catalyst $\mathrm{Pt} / \gamma$ $\mathrm{Al}_{2} \mathrm{O}_{3}$ of $543 \mathrm{~K}$. Therefore, steam reforming can take place simultaneously when the inlet feed is fed into the reformer because oxidation provides the extra energy supplement.
For a self-sustained double-jacketed membrane reactor, the system can be run without additional fuel feeding because the un-converted methanol and un-permeated hydrogen is oxidized to provide the endothermic reforming. However, an extra methanol/air flow is needed in the oxidation side because no hydrogen is produced in the beginning when the reformer is starting up. The extra methanol feeding can be stopped after the reformer reaches steady state, and then the double-jacketed reactor is operated under self-sustained condition. During the start-up period, the ratio of methanol mass flow rate between oxidation side and reformer is set to be 0.1 . The reason of choosing 0.1 is because the enthalpy generated by methanol oxidation in oxidation side can meet the requirement of methanol steam reforming according to the theoretical energy balance estimation. An assumption of excess oxygen is proposed to ensure the total oxidation of methanol, thus the ratio of mass flow rate of air and methanol in oxidation side is set to be a little larger than 5 .

Fig. 2 illustrates the temperature distributions as a function of reformer length at different times under condition (1) operation. The reformer starts when the catalyst bed is cold, the hot stream and external fuel combustion is used to heat up the catalyst bed, indicating the increasing temperature profile near the entrance of reformer. Then the steam reforming reaction adsorbs heat, cools down the temperature in the rear part of reformer. Furthermore, it can also be found that during the transient period, the temperature difference between gases and catalyst diminishes with reformer position, and maintains a difference of approximately $5 \mathrm{~K}$ when the reformer reaches steady state. This means that the heat transfer is from gases to catalyst bed, where the endothermic reforming reaction cools down the temperature on the catalyst surface.

Fig. 3 shows the molar fractions of species at the exit of reformer as a function of dimensionless time under condition (1) operation. The molar fractions of methanol and steam decreases monotonically with time during the transient period, leading to an increase in hydrogen, carbon dioxide and very little carbon monoxide production. The molar fractions of each species reach steady state when the dimensionless

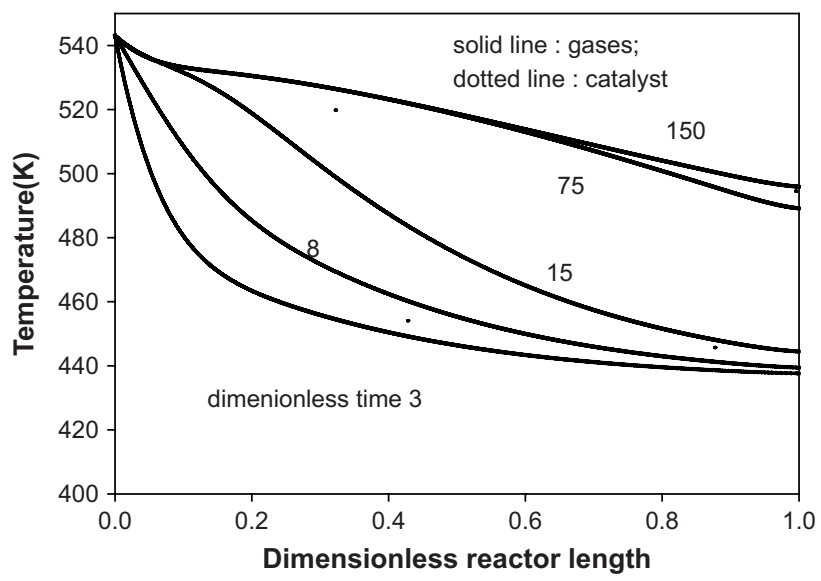

Fig. 2 - Gases and catalysts temperature profiles as a function of dimensionless length under condition 1 (hot stream $(543 \mathrm{~K})$ is fed in to cold reformer $(433 \mathrm{~K}))$. WHSV of methanol is $20 \mathrm{~h}^{-1}, R_{\mathrm{W} / \mathrm{M}}$ is 1.2 , reformer pressure is 5 bar. 


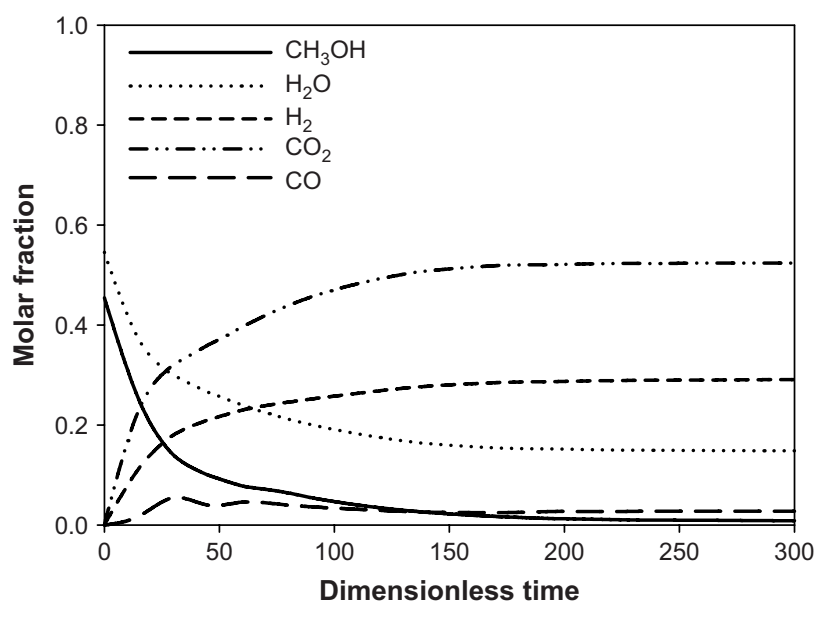

Fig. 3 - The molar fractions of species in reformer as a function of dimensionless time under condition 1 (hot stream $(543 \mathrm{~K})$ is fed in to cold reformer $(433 \mathrm{~K}))$. WHSV of methanol is $20 \mathrm{~h}^{-1}, R_{\mathrm{W} / \mathrm{M}}$ is 1.2 , reformer pressure is 5 bar.

time is about 150. This indicates that, in the beginning, most of the enthalpy carried by the hot stream is consumed to raise the temperature of catalyst bed instead of supplying to the reforming reaction, resulting in a low conversion of methanol and steam. When the temperature of the catalyst bed is high enough, the reforming reaction takes over. The catalyst bed is continuously heated by the hot stream and external catalytic oxidation of methanol, but it is also simultaneously cooled down by the endothermic reaction. An increasing tendency of the temperature in Fig. 2 indicates the increasing consumption rate of methanol and steam because the reforming rate is proportional to the catalyst surface temperature. In addition, the theoretical hydrogen production is three times higher than the production of carbon dioxide; however, the molar fraction of hydrogen in the reformer is less than that of carbon dioxide because part of the hydrogen permeates into the permeator. Nearly $0.1 \%$ of carbon monoxide is observed under condition (1) operation because the temperature of catalyst bed is always lower than $510 \mathrm{~K}$, favoring water gas shifting but not methanol decomposition.

Fig. 4 depicts the temperature distributions as a function of reformer length in time sequence under condition (2) operation. The reformer is preheated to the working temperature $(543 \mathrm{~K})$, and a cold stream $(433 \mathrm{~K})$ is fed into the hot reformer. The results show a significantly increasing trend of gaseous temperature profiles at the entrance of reformer, and then maintain a slightly increasing trend in the rear part of reformer. During the transient period, the temperature curves of catalyst bed keep monotonically increasing in the reformer. Then the catalyst temperature gradually decreases when it reaches steady state. This indicates that, initially, the cold stream is heated by the hot catalyst bed and external combustor. Then the steam reforming absorbs enthalpy from the catalyst surface, indicating the decreasing trend of the catalyst bed temperature as time increases. During the transient period, the reformer temperature increases slightly in the rear part of reformer because methanol is almost completely converted, and the heat from the catalytic combustor is provided to heat

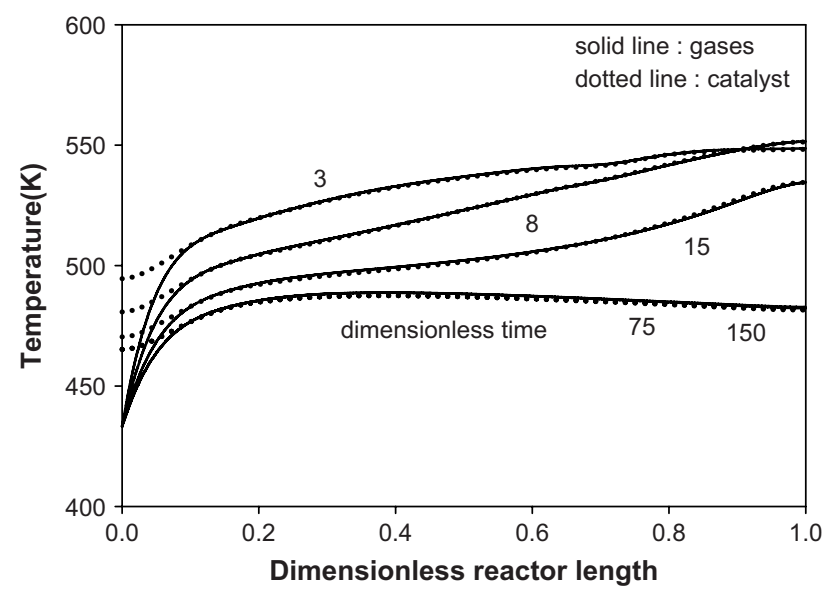

Fig. 4 - Gases and catalysts temperature profiles as a function of dimensionless length under condition 2 (cold stream $(433 \mathrm{~K})$ is fed in to hot reformer $(543 \mathrm{~K})$ ). WHSV of methanol is $20 \mathrm{~h}^{-1}, R_{\mathrm{W} / \mathrm{M}}$ is 1.2 , reformer pressure is 5 bar.

up the reformer temperature. When it reaches steady state, the catalyst temperature is lower than that in the beginning because the cold gas stream and endothermic reforming keeps absorbing heat from catalyst. The slightly decreasing trend in the rear part of reformer temperature under steady state (dimensionless time 150) is because the heat consumed by reforming is slightly higher than that supplied by external heat transfer.

Fig. 5 shows the molar fractions of species at the exit of reformer as a function of dimensionless time under condition (2) operation. Initially, methanol and steam is consumed rapidly when the feedstock is fed in, accompanied with large production of hydrogen, carbon dioxide, and carbon monoxide. The methanol and steam conversion decrease with time after 20 dimensionless time, and reach steady state after about 100 dimensionless time. This means that, initially, the reforming reaction occurs simultaneously when the cold

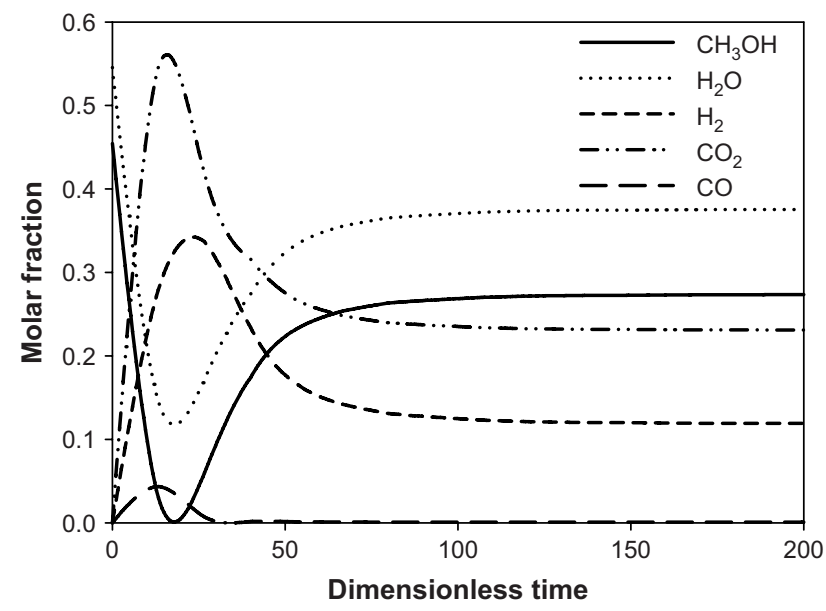

Fig. 5 - The molar fractions of species in reformer as a function of dimensionless time under condition 2(cold stream $(433 \mathrm{~K})$ is fed in to hot reformer $(543 \mathrm{~K}))$. WHSV of methanol is $20 \mathrm{~h}^{-1}, R_{\mathrm{W} / \mathrm{M}}$ is 1.2, reformer pressure is $5 \mathrm{bar}$. 
stream flows to the hot catalyst surface, leading to the high methanol conversion. Then the cold inlet feed keeps cooling down the catalyst bed, resulting in a lower reforming rate and methanol conversion, as compared with those in the beginning. In addition, endothermic reforming also uptakes part of thermal energy from the catalyst. When it reaches steady state, the methanol conversion under condition (2) operation is lower than that under condition (1) operation because the temperature on the catalyst surface is lower than that under condition (1) operation.

The maximum molar fraction of hydrogen has a time lag over other species. This indicates that the maximum consumption of methanol results in the maximum production of hydrogen; meanwhile, the high hydrogen concentration in the reformer drives part of the hydrogen permeating into the permeator, thus competition between hydrogen production and permeation causes the lag of maximum hydrogen molar fraction. The production rate of carbon dioxide is proportional to the consumption rate of methanol, and it is found that carbon dioxide yields more than $30 \%$ in the effluents if a part of hydrogen permeates into the permeator. In addition, nearly $5 \%$ of carbon monoxide is observed in the first 20 dimensionless time because the hot catalyst surface decomposes a part of methanol resulting in a high concentration of undesired carbon monoxide.

A summary can be made from the results above. When it is operated under condition (1), the reformer has low methanol conversion and temperature of reformer in the beginning, while high methanol conversion and temperature of reformer is exhibited when it reaches steady state. Meanwhile, condition (1) operation also ensures a low concentration variation due to its low reforming rate during the transient period. Therefore, choosing condition (1) operation can result in more steady species concentrations than under condition (2) operation. On the contrary, operating under condition (2) results in high methanol conversion and reformer temperature in the beginning, but methanol conversion and temperature of reformer is not high when it reaches steady state. In addition, operating under condition (2) can have a short start-up time as compared to that under condition (1) operation. Therefore we can conclude that the catalyst should be preheated to a high temperature if a short start-up time and fast hydrogen yield is desired. However, it causes a fluctuation of species concentrations and low methanol conversion when it reaches steady state. Moreover, more $\mathrm{CO}$ is formed during the first 20 dimensionless time. On the other hand, the gas stream should be preheated to a high temperature if high methanol conversion and hydrogen yield is required at steady state.

\subsection{Fluctuation during steady-state operation}

When the reformer is operated under steady state, one might need to adjust the settings if some special requirements were made. For instance, the methanol or steam supplement is suddenly changed, an unusual reformer temperature drop occurs, or an extra hydrogen demand is required. Chan et al. used a 2-D heterogeneous model to simulate the transient performance of autothermal methane steam reforming [29]. Three step-up and step-down reactor fluctuations were analyzed. The overshoot/undershoot of species and temperature is also discussed. However the transient study of membrane reactors is not be explored. In this study, we thought of an extra hydrogen demand as a simulation example and analyzed the results via methanol conversion, temperature variation, and relative hydrogen production fluctuation. The extra hydrogen demand is set to be 1.5 times the ordinary production. Two scenarios are considered, first, the methanol feed rate in the reformer is increased to meet this demand. The extra hydrogen demand lasts for 300 dimensionless time. Fig. 6 shows the responses of the methanol conversion, reformer temperature, and relative hydrogen production as a function of dimensionless time. The response time of methanol conversion is about 40 dimensionless time, while the response time of the reformer temperature is larger than that of methanol conversion. The time lag of reformer temperature from methanol conversion is because when methanol conversion decreases as the mass flow rate increases, it takes time to transfer heat from the oxidation side to the reformer, leading to the time lag of temperature.

Fig. 6 also shows that an offset of relative hydrogen production occurs in the beginning of the pulse. Relative hydrogen production is the ratio of transient-period rate to ordinary rate of hydrogen. Although increasing methanol and steam mass flow rate allows for extra hydrogen production, such operation sacrifices reforming efficiency by lowering methanol conversion and reforming temperature. In other words, more than 1.5 times of methanol is required to meet the extra hydrogen demand. The original reactor is optimized for maximum methanol conversion and hydrogen yield. Therefore, if long-term extra hydrogen demand is required, the reactor size should be enlarged instead of increasing methanol feed.

Another way to increase the temporary hydrogen production is to raise the reformer temperature by feeding extra methanol to the oxidation side. Increasing fuels in the oxidation side can increase the temperature of the oxidation side, leading to a higher thermal driving force from oxidation side to reformer. Fig. 7 illustrates the responses of methanol conversion, reformer temperature, and relative hydrogen production against dimensionless time. The extra methanol required in the oxidation side is estimated to increase $15 \%$ of methanol consumption. The methanol conversion of the reformer can only increase slightly because prior steady-state conversion is already high. This suggests that most of the extra enthalpy

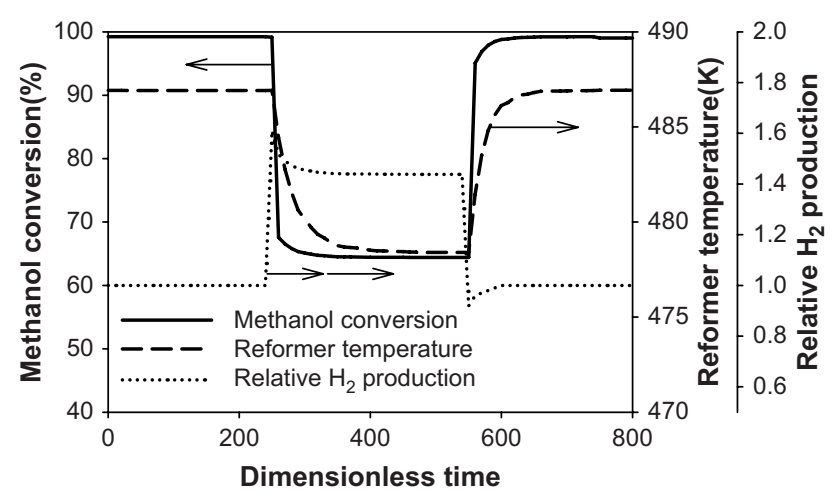

Fig. 6 - The responses of methanol conversion, reformer temperature, and relative hydrogen production as a function of dimensionless time with an extra hydrogen demand. 


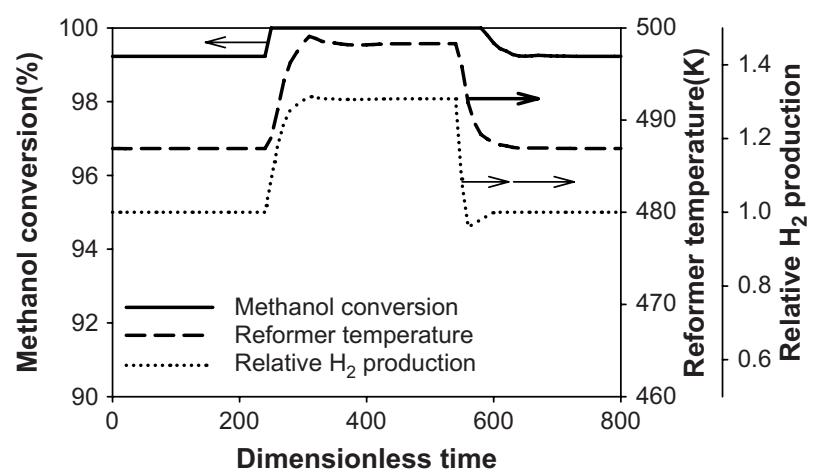

Fig. 7 - The responses of methanol conversion, reformer temperature, and relative hydrogen production as a function of dimensionless time with an extra hydrogen demand.

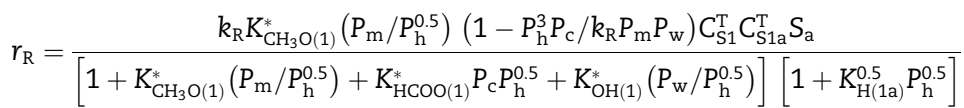

Kinetics of methanol steam reforming over $\mathrm{CuO} / \mathrm{ZnO} / \mathrm{Al}_{2} \mathrm{O}_{3}$ Methanol steam reforming

$\mathrm{CH}_{3} \mathrm{OH}+\mathrm{H}_{2} \mathrm{O} \leftrightarrow \mathrm{CO}_{2}+3 \mathrm{H}_{2}, \quad \Delta \mathrm{H}_{298 \mathrm{~K}}=49.4 \mathrm{~kJ} \mathrm{~mol}^{-1}$

Financial support by the Ministry of Economic Affairs, Taiwan, under grant 95-EC-17-A-09-S1-019 is gratefully acknowledged.

\section{Appendix.}

$P_{\mathrm{h}}^{0.5}$

from the oxidation side is used to raise the reformer temperature, which is also observed in Fig. 7. The response time of methanol conversion is almost the same as reformer temperature because methanol is completely consumed when reformer temperature increases. In addition, only near $30 \%$ increase of hydrogen production is observed in Fig. 7 because near all of the hydrogen has permeated into the permeator. This suggests a maximum extra hydrogen production with an increasing reformer temperature. However, increasing reformer temperature is not a good idea because such operation needs extra methanol for heating from the oxidation side, and cannot meet 1.5 times hydrogen demand. Furthermore, high temperature favors $\mathrm{CO}$ production.

In summary, increasing the inlet mass flow rate is more appropriate than increasing reformer temperature for a temporary extra hydrogen demand. But, neither one fits the high efficiency of the reformer for long-term usage.

\section{Conclusion}

A simulation of an unsteady-state double-jacketed membrane reactor is presented. The start-up of a double-jacketed membrane reactor is evaluated under two conditions. A short start-up time is found in either condition. We recommend that initial temperature of catalyst bed is higher than inlet gas because of high methanol conversion and temperature at steady state. In addition, the instability of species can be minimized because of low reaction rate during the transient period. When an extra hydrogen demand is required, increasing the inlet methanol can meet the requirement while
Methanol decomposition

$$
\begin{aligned}
& \mathrm{CH}_{3} \mathrm{OH} \leftrightarrow \mathrm{CO}+2 \mathrm{H}_{2}, \quad \Delta \mathrm{H}_{298 \mathrm{~K}}=90.5 \mathrm{~kJ} \mathrm{~mol}^{-1} \\
& r_{\mathrm{D}}=\frac{k_{\mathrm{D}} K_{\mathrm{CH}_{3} \mathrm{O}(2)}^{*}\left(P_{\mathrm{m}} / \mathrm{P}_{\mathrm{h}}^{0.5}\right)\left(1-P_{\mathrm{h}}^{2} \mathrm{P}_{\mathrm{co}} / k_{\mathrm{D}} P_{\mathrm{m}}\right) C_{\mathrm{S} 2}^{\mathrm{T}} C_{\mathrm{S} 2 \mathrm{a}}^{\mathrm{T}} \mathrm{S}_{\mathrm{a}}}{\left[1+K_{\mathrm{CH}_{3} \mathrm{O}(2)}\left(P_{\mathrm{m}} / P_{\mathrm{h}}^{0.5}\right)+K_{\mathrm{OH}(2)}^{*}\left(P_{\mathrm{w}} / P_{\mathrm{h}}^{0.5}\right)\right]\left[1+K_{\mathrm{H}(2 \mathrm{a})}^{0.5} P_{\mathrm{h}}^{0.5}\right]}
\end{aligned}
$$

Water gas shift reaction

$\mathrm{CO}+\mathrm{H}_{2} \mathrm{O} \leftrightarrow \mathrm{CO}_{2}+\mathrm{H}_{2}, \quad \Delta \mathrm{H}_{298 \mathrm{~K}}=-41.1 \mathrm{~kJ} \mathrm{~mol}^{-1}$
Table A.1 - The parameters relate to the kinetics of methanol steam reforming, methanol decomposition, and water gas shift reaction.

\begin{tabular}{ll}
$k_{\mathrm{R}}\left(\mathrm{m}^{2} \mathrm{~mol}^{-1} \mathrm{~s}^{-1}\right)$ & $7.4 \times 10^{14} \mathrm{e}^{-102,800 / \mathrm{RT}}$ \\
$\mathrm{K}_{\mathrm{CH}}^{*} \mathrm{O}(1)\left(\mathrm{bar}^{-0.5}\right)$ & $6.55 \times 10^{-3} \mathrm{e}^{20,000 / \mathrm{RT}}$ \\
$\mathrm{K}_{\mathrm{HCOO}(1)}^{*}\left(\mathrm{bar}^{-1.5}\right)$ & $2.3 \times 10^{9} \mathrm{e}^{-100,000 / \mathrm{RT}}$ \\
$\mathrm{K}_{\mathrm{OH}(1 \mathrm{a})}^{*}\left(\mathrm{bar}^{-0.5}\right)$ & $4.74 \times 10^{-3} \mathrm{e}^{20,000 / \mathrm{RT}}$ \\
$\mathrm{K}_{\mathrm{H}(1 \mathrm{a})}\left(\mathrm{bar}^{-0.5}\right)$ & $5.43 \times 10^{-6} \mathrm{e}^{50,000 / \mathrm{RT}}$ \\
$k_{\mathrm{D}}\left(\mathrm{m}^{2} \mathrm{~mol}^{-1} \mathrm{~s}^{-1}\right)$ & $3.8 \times 10^{20} \mathrm{e}^{-170,000 / \mathrm{RT}}$ \\
$\mathrm{K}_{\mathrm{CH}}^{*} \mathrm{O}(1)\left(\mathrm{bar}^{-0.5}\right)$ & $3.69 \times 10^{1} \mathrm{e}^{20,000 / \mathrm{RT}}$ \\
$\mathrm{K}_{\mathrm{OH}(2)}^{*}\left(\mathrm{bar}^{-0.5}\right)$ & $3.69 \times 10^{1} \mathrm{e}^{20,000 / \mathrm{RT}}$ \\
$\mathrm{K}_{\mathrm{H}(2 \mathrm{a})}\left(\mathrm{bar}^{-0.5}\right)$ & $3.86 \times 10^{-3} \mathrm{e}^{50,000 / \mathrm{RT}}$ \\
$k_{\mathrm{W}}\left(\mathrm{m}^{2} \mathrm{~mol}^{-1} \mathrm{~s}^{-1}\right)$ & $5.9 \times 10^{13} \mathrm{e}^{-87,600 / \mathrm{RT}}$ \\
$C_{\mathrm{S} 1}^{\mathrm{T}}=C_{\mathrm{S} 2}^{\mathrm{T}}\left(\mathrm{m}^{-2} \mathrm{~mol}\right)$ & $7.5 \times 10^{-6}$ \\
$C_{\mathrm{S} 1 \mathrm{a}}^{\mathrm{T}}=C_{\mathrm{S} 2 \mathrm{a}}^{\mathrm{T}}\left(\mathrm{m}^{-2} \mathrm{~mol}\right)$ & $1.5 \times 10^{-5}$ \\
\hline
\end{tabular}




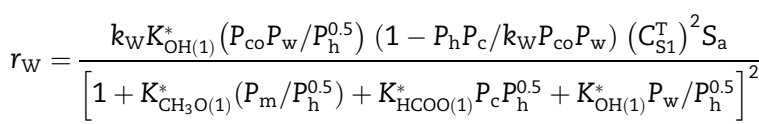

where $P_{m}$ is the partial pressure of methanol, $P_{\mathrm{w}}$ is the partial pressure of water, $P_{h}$ is the partial pressure of hydrogen, $P_{c}$ is the partial pressure of carbon dioxide, and $P_{\text {co }}$ is the partial pressure of carbon monoxide. The corresponding parameters are listed in Table A.1. [16,23,24]

\section{R E F E R E N C E S}

[1] Uemiya S, Sato N, Ando H, Matsuda T, Kikuchi E. Steam reforming of methane in a hydrogen-permeable membrane reactor. Appl Catal 1991;67(2):223-30.

[2] Collins JP, Way JD. Preparation and characterization of a composite palladium-ceramic membrane. Ind Eng Chem Res 1993;32(12):3006-13.

[3] Lin YM, Lee GL, Rei MH. An integrated purification and production of hydrogen with a palladium membranecatalytic reactor. Catal Today 1998;44(1-4):343-9.

[4] Armor JN. The multiple roles for catalysis in the production of H-2. Appl Catal A 1999;176(2):159-76.

[5] Breen JP, Ross JRH. Methanol reforming for fuel-cell applications: development of zirconia-containing $\mathrm{Cu}-\mathrm{Zn}-\mathrm{Al}$ catalysts. Catal Today 1999;51(3-4):521-33.

[6] Itoh N. A membrane reactor using palladium. AICHE J 1987; 33(9):1576-8.

[7] Itoh N, Govind R. Combined oxidation and dehydrogenation in a palladium membrane reactor. Ind Eng Chem Res 1989; 28(10):1554-7.

[8] Jenkins JW, Shutt E. Hydrogen generation using a novel concept. Platinum Metals Rev 1989;33:118-27.

[9] Hohlein B, Boe M, Bogild-Hansen J, Brockerhoff P, Colsman G, Emonts B, et al. Hydrogen from methanol for fuel cells in mobile system: development of a compact reformer. J Power Sources 1996;61(1-2):143-7.

[10] Geissler K, Newson E, Vogel F, Truong TB, Hottinger P, Wokaun A. Autothermal methanol reforming for hydrogen production in fuel cell applications. Phys Chem Chem Phys 2001;3(3):289-93.

[11] Mizsey P, Newson E, Truong TB, Hottinger P. The kinetics of methanol decomposition: a part of autothermal partial oxidation to produce hydrogen for fuel cells. Appl Catal A 2001;213(2):233-7.

[12] De Goote AM, Froment GF. Simulation of the catalytic partial oxidation of methane to synthesis gas. Appl Catal A 1996; 138(2):245-64.
[13] Han J, Kim IS, Choi KS. High purity hydrogen generator for on-site hydrogen production. Int J Hydrogen Energy 2002; 27(10):1043-7.

[14] Harold MP, Nair B, Kolios G. Hydrogen generation in a Pd membrane fuel processor: assessment of methanol-based reaction systems. Chem Eng Sci 2003;58(12):2551-71.

[15] Lattner JR, Harold MP. Comparison of conventional and membrane reactor fuel processors for hydrocarbon-based PEM fuel cell system. Int J Hydrogen Energy 2004;29(4): 393-417.

[16] Lattner JR, Harold MP. Comparison of methanol-based fuel processors for PEM fuel cell systems. Appl Catal B 2005; 56(1-2):149-69.

[17] Ji P, van der Kooi HJ, Arons JD. Simulation and thermodynamic analysis of an integrated process with $\mathrm{H}-2$ membrane CPO reactor for pure H-2 production. Chem Eng Sci 2003;58(17):3901-11.

[18] Hoang DL, Chan SH. Modeling of a catalytic autothermal methane reformer for fuel cell applications. Appl Catal A 2004;268(1-2):207-16.

[19] Chan SH, Wang HM. Thermodynamic and kinetic modeling of an autothermal methanol reformer. J Power Sources 2004; 126(1-2):8-15.

[20] Hoang DL, Chan SH, Ding OL. Kinetic and modeling study of methane steam reforming over sulfide nickel catalyst on a gamma alumina support. Chem Eng J 2005;112(1-3):1-11.

[21] Papadias D, Lee SHD, Chmielewski DJ. Autothermal reforming of gasoline for fuel cell applications: a transient reactor model. Ind Eng Chem Res 2006;45(17):5841-58.

[22] $\mathrm{Fu} \mathrm{CH}, \mathrm{Wu}$ JCS. Mathematical simulation of hydrogen production via methanol steam reforming using doublejacketed membrane reactor. Int J Hydrogen Energy 2007; 32(18):4830-9.

[23] Peppley BA, Amphlett JC, Kearns LM, Mann RF. Methanolsteam reforming on $\mathrm{Cu} / \mathrm{ZnO} / \mathrm{Al}_{2} \mathrm{O}_{3}$. Part 1: the reaction network. Appl Catal A 1999;179(1-2):21-9.

[24] Peppley BA, Amphlett JC, Kearns LM, Mann RF. Methanol-steam reforming on $\mathrm{Cu} / \mathrm{ZnO} / \mathrm{Al}_{2} \mathrm{O}_{3}$ catalysts. Part 2. A comprehensive kinetic model. Appl Catal A 1999;179(1-2):31-49.

[25] Pasel J, Emonts B, Peters R, Stolten D. A structured test reactor for the evaporation of methanol on the basis of a catalytic combustion. Catal Today 2001;69(1-4):193-200.

[26] Froment GF, Bischoff KB. Chemical reactor analysis and design. 2nd ed. New York, NY: John Wiley \& Sons, Inc.; 1990.

[27] Bird RB, Stewart WE, Lightfoot EN. Transport phenomena. 2nd ed. New York, NY: John Wiley \& Sons, Inc.; 1990.

[28] Perry R, Green D, Maloney J. Perry's chemical engineers' handbook. 7th ed. New York, NY: McGraw Hill, Inc.; 1999.

[29] Chan SH, Hoang DL, Ding OL. Transient performance of an autothermal reformer - a 2-D modeling approach. Int J Heat Mass Transfer 2005;48(19-20):4205-14. 